Annals of Warsaw University of Life Sciences - SGGW

Land Reclamation No 42 (1), 2010: 187-196

(Ann. Warsaw Univ. of Life Sci. - SGGW, Land Reclam. 42 (1), 2010)

\title{
On the erosion due to inclined jets
}

\author{
LORENZO MINATTI, ENIO PARIS, LUCA SOLARI \\ Department of Civil and Environmental Engineering, Firenze University, Italy
}

\begin{abstract}
On the erosion due to inclined jets. Some preliminary experiments and studies regarding scour processes on a mobile bed caused by inclined jets issuing from a sluice gate are presented. Tests with submerged tailwater conditions have been carried out using different flow and geometric conditions. The investigated experimental conditions included different jet Froude numbers, inclinations and tailwater conditions. The bed configuration has been measured during the whole scour hole evolution process until the achievement of a dynamic steady state, where sediment motion was still possible even though it did not allow for any persistent change in the scour and ridge shapes anymore. On the basis of the observed sediment motion, two different patterns of flow seem to develop under the investigated conditions: one where the main flow remains attached to the bottom of the channel and another where it oscillates between the aforementioned configuration and a surface jet. Some relevant parameters have been identified and used to plot graphs showing their correlation and trends.
\end{abstract}

Key words: Jets, Regime, Scour.

\section{INTRODUCTION}

Erosion due to jets is a problem of considerable importance in hydraulic structures design. It may cause structural collapse if its extent results in foundation damages. So, the ability to predict the maximum scour extent (both in terms of length and depth) is of great importance in designing this kind of structures, as it affects their durability.
The physics of the problem is quite complicated as turbulence and the mechanism of interaction between the grains and the jet are involved. Nevertheless, empirical relations to predict the maximum scour depth and other relevant parameters of the process, have been developed by researchers in the past.

Many authors have studied scour caused by plane turbulent jets on an incoherent material bed.

Rajaratnam (1981) conducted experiments with deeply submerged jets on a sandy bed, finding a simple relation between the maximum scour and the jet densimetric Froude number (to be defined ahead). Rajaratnam and Macdougall (1983) extended the set of experiments previously carried out by Rajaratnam (1981), considering jets with low tailwater depths on a sandy bed; they found the geometric features of the scour hole to be mainly dependent on the densimetric Froude number once again and found lower maximum scour depths than in the case of submerged jets. They also noticed some oscillations of the jet, which was switching its direction between the water surface and the bottom of the bed. These oscillations were reported to fade as the steady state was reached.

Ali and Lim (1986) carried out tests with plane jets on a sandy bed by using 
low to medium tailwater depths and different jet densimetric Froude numbers. They developed a formula for maximum scour depth prediction by interpolating data resulting from their and other authors experiments. When analyzing the data collected from their experiments, they noticed the existence of a critical value of tailwater depth minimizing the maximum scour depth and a limit value beyond which the maximum scour depth depended on the jet densimetric Froude number only. Similar conclusions regarding tailwater depth have been drawn also by Sarathi et al. (2008), even though their observations regarding the tailwater depth limit value are quantitatively different from the ones made by Ali and Lim (1986).

Johnston (1990), when carrying out experiments on plane jets on mobile beds identified three different scourhole regimes: one when the jet stays attached to the surface, one where it stays attached to the bed and another one where it oscillates periodically between these two configurations, without reaching a steady asymptotic state. He indicated the initial jet offset (i.e. scour depth at the initial scour cross section) as the parameter mostly affecting the jet regime and explored the conditions determining a certain regime. He found tailwater depth to be important as well, and found high tailwater depth conditions to produce jets with a bed regime. Similar observations have been made also by Espa and Sibilla (2006), Nik Hassan and Narayanan (1985).

In this study, the variation of the scourhole geometric features with respect to the jet hydraulic parameters and tailwater depth conditions is investigated. Besides the parameters that have been taken into account in the afore mentioned studies, an emphasis is given on the jet impinging angle.

\section{MATERIALS AND METHODS}

\section{Experimental setup}

The tests were carried out at the Hydraulics Laboratory of The Civil and Environmental Engineering Department of the University of Florence by using a $120 \mathrm{~cm}$ long and $10.7 \mathrm{~cm}$ wide flume with perspex walls. The high length/width ratio of the flume restricted our range of study to two dimensional flows.

A constant flow rate of $2.3 \mathrm{l} / \mathrm{s}$ (used for the whole set of experiments) was supplied by a pump located into a tank under the downstream end of the flume. Flow rate was measured by an electromagnetic flow meter installed along the pipe. The jet thickness was set by regulating the opening of a sluice gate located at the upstream end of the flume. At the sluice gate opening different wedge shaped rigid aprons were installed in order to obtain jets with various inclinations. Tailwater depth was then set by regulating the height of a weir at the downstream end of the flume. The flume bed was filled with almost uniform grains of about $7.3 \mathrm{~mm}$ diameter and a sand trap was placed between the flume outlet pipe and the pump tank to prevent sediments from damaging the pump apparatus. Density of material was around $2650 \mathrm{~kg} / \mathrm{m}^{3}$. A gridded transparent panel was placed on the wall of the flume to allow scour geometry measurements. The measuring reach inside the flume was $90 \mathrm{~cm}$ long. A sketch (not to scale) of the flume is reported in Figure 1, along with the definition of the parameters and geometric features of the problem. 


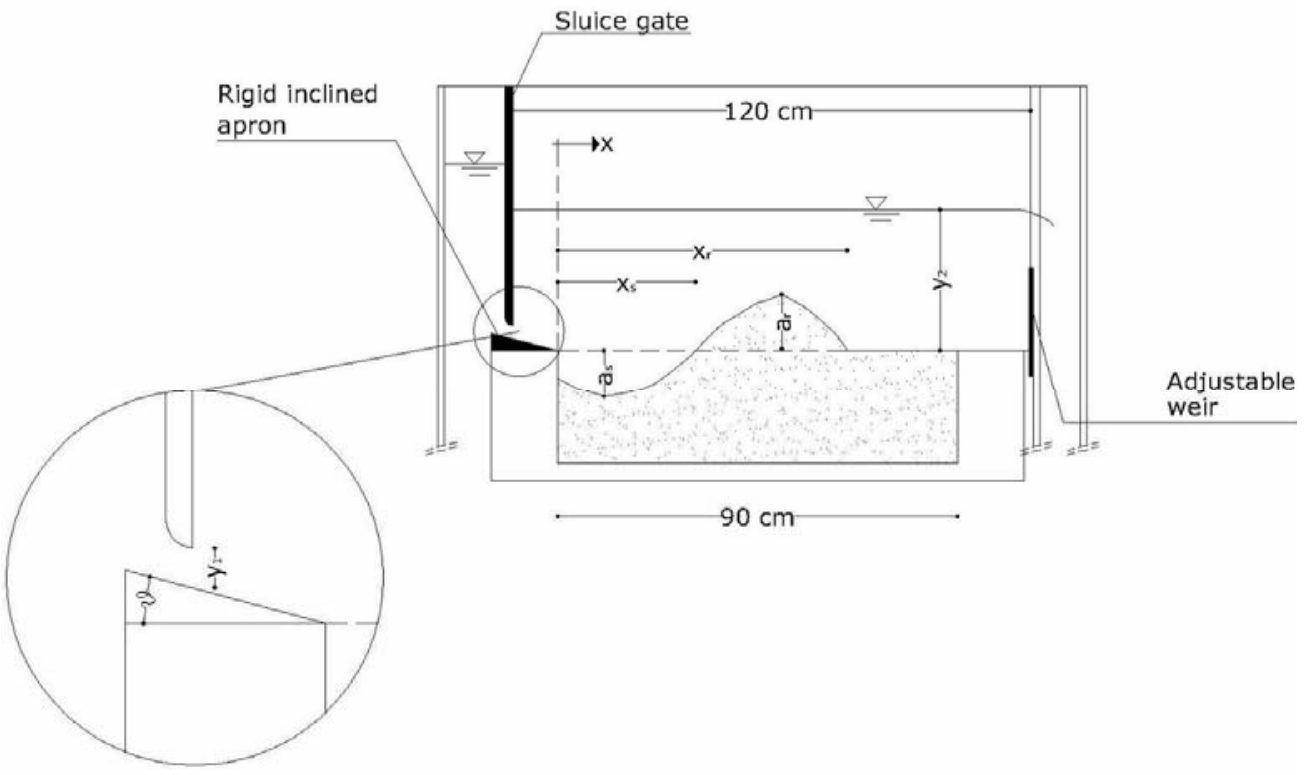

FIGURE 1. Sketch of experimental apparatus

TABLE 1. Test Parameters

\begin{tabular}{|c|c|c|c|c|c|c|c|}
\hline Run id. & $\begin{array}{c}\text { Run prog. } \\
\text { number [RPG] }\end{array}$ & $F_{d}[]$ & $\mathrm{S}[]$ & $\begin{array}{c}\Theta \\
{\left[{ }^{\circ}\right]}\end{array}$ & $\begin{array}{c}y_{1} \\
{[\mathrm{~mm}]}\end{array}$ & $\begin{array}{c}U_{1} \\
{[\mathrm{~m} / \mathrm{s}]}\end{array}$ & $\begin{array}{c}\text { Test } \\
\text { duration }\end{array}$ \\
\hline $\mathrm{A} 0 \beta 0$ & 01 & 2.32 & 2.08 & 0 & 29 & 0.80 & $4 \mathrm{~h} 10 \mathrm{~m}$ \\
\hline $\mathrm{A} 0 \gamma 0$ & 02 & 2.32 & 2.95 & 0 & 29 & 0.80 & $2 \mathrm{~h} 20 \mathrm{~m}$ \\
\hline $\mathrm{A} 0 \lambda 0$ & 03 & 2.32 & 6.94 & 0 & 29 & 0.80 & $13 \mathrm{~h} 50 \mathrm{~m}$ \\
\hline $\mathrm{A} 2 \beta 0$ & 04 & 3.68 & 3.02 & 0 & 18 & 1.27 & $25 \mathrm{~h} 55 \mathrm{~m}$ \\
\hline $\mathrm{A} 2 \gamma 0$ & 05 & 3.68 & 5.49 & 0 & 18 & 1.27 & $1 \mathrm{~h} 35 \mathrm{~m}$ \\
\hline $\mathrm{A} 2 \lambda 0$ & 06 & 3.68 & 10.99 & 0 & 18 & 1.27 & $6 \mathrm{~h} 55 \mathrm{~m}$ \\
\hline $\mathrm{A} 3 \beta 0$ & 07 & 5.18 & 5.04 & 0 & 13 & 1.78 & $7 \mathrm{~h} 40 \mathrm{~m}$ \\
\hline $\mathrm{A} 3 \gamma 0$ & 08 & 5.18 & 8.53 & 0 & 13 & 1.78 & $8 \mathrm{~h} 25 \mathrm{~m}$ \\
\hline $\mathrm{A} 3 \lambda 0$ & 09 & 5.18 & 15.50 & 0 & 13 & 1.78 & $28 \mathrm{~h} 30 \mathrm{~m}$ \\
\hline $\mathrm{A} 0 \beta 15$ & 10 & 2.32 & 1.74 & 15 & 29 & 0.80 & $7 \mathrm{~h}$ \\
\hline $\mathrm{A} 0 \gamma 15$ & 11 & 2.32 & 2.95 & 15 & 29 & 0.80 & $19 \mathrm{~h} 35 \mathrm{~m}$ \\
\hline A0ג15 & 12 & 2.32 & 6.94 & 15 & 29 & 0.80 & $18 \mathrm{~h} 40 \mathrm{~m}$ \\
\hline $\mathrm{A} 2 \beta 15$ & 13 & 3.68 & 2.75 & 15 & 18 & 1.27 & $21 \mathrm{~h}$ \\
\hline $\mathrm{A} 2 \gamma 15$ & 14 & 3.68 & 4.95 & 15 & 18 & 1.27 & $27 \mathrm{~h} 25 \mathrm{~m}$ \\
\hline $\mathrm{A} 2 \lambda 15$ & 15 & 3.68 & 10.99 & 15 & 18 & 1.27 & $16 \mathrm{~h} 15 \mathrm{~m}$ \\
\hline $\mathrm{A} 3 \beta 15$ & 16 & 5.18 & 4.26 & 15 & 13 & 1.78 & $11 \mathrm{~h} 30 \mathrm{~m}$ \\
\hline $\mathrm{A} 3 \gamma 15$ & 17 & 5.18 & 7.75 & 15 & 13 & 1.78 & $15 \mathrm{~h} 05 \mathrm{~m}$ \\
\hline $\mathrm{A} 3 \lambda 15$ & 18 & 5.18 & 15.50 & 15 & 13 & 1.78 & $20 \mathrm{~h} 05 \mathrm{~m}$ \\
\hline
\end{tabular}


At the beginning of every test the bed was leveled and weir height and sluice gate opening were regulated. After the pump was started, flow rate was gradually increased by operating on a valve installed along the pipe, until the bed shear stress approached the critical value for sediments motion. When critical value was reached, the valve was quickly opened in order to reach the desired flow rate as suddenly as possible.

Table 1 reports a list of the run tests and their parameters, as defined in the next paragraph (note that jet velocity $U_{1}$ is calculated from the ratio between flow rate and sluice gate opening area).

Parameters of the experiments were also chosen in order not to have bed load transport at undisturbed flow conditions i.e. far away from the scourhole.

\section{Dimensional analysis}

Considering 2D jets by using a jet as wide as the flume (i.e. expansion ratio $=1: 1$ ), considering aprons of different inclinations, jet of different thickness and using different tailwater depths, a generic feature $\Phi$ of the flow field or of the scour geometry can be expressed as a function of the parameters defining the flow and the geometry of the problem:

$$
\Phi=f\left(U_{1}, \rho_{s}, \rho, \mu, y_{1}, y_{2}, D, t, \vartheta\right)
$$

where the notation is as follows:

- $U_{1}$ is the jet average velocity at the sluice gate opening,

- $\rho_{s}$ is the sediments density,

- $\rho$ is the fluid (water) density,

- $\mu$ is the fluid (water) dynamic viscosity,

- $y_{1}$ is the jet thickness,

- $y_{2}$ is the tailwater depth,
- $D$ is the sediments diameter (sediments with uniform diameter are being used),

- $t$ is the time of scouring action,

- $\theta$ is the apron inclination angle.

By using dimensional analysis (Ali and Lim 1986; Johnston 1990; Rajaratnam 1981) and using $y_{1}$ as a length scale, the generic scaled problem feature $N_{\Phi}$ can be represented as a function of non dimensional parameters in the following way:

$$
N_{\Phi}=f\left(s, \operatorname{Re}, F_{d}, S, \frac{y_{1}}{D}, \frac{U_{1} t}{y_{1}}, \vartheta\right)
$$

where:

$s=\frac{\rho_{s}-\rho}{\rho}-$ is the specific gravity,

$\operatorname{Re}=\frac{\rho U_{1} y_{1}}{\mu}-\begin{aligned} & \text { is the jet Reynolds } \\ & \text { number, }\end{aligned}$

$F_{d}=\frac{U_{1}}{\sqrt{\frac{\rho_{s}-\rho}{\rho} g D}}-$ is the densimetric $S=\frac{y_{2}}{y_{1}}-$ is the flow submergence,

$\frac{y_{1}}{D} \quad-$ is the relative roughness, $t^{*}=\frac{U_{1} t}{y_{1}}-$ is a scaled time parameter.

Some authors reported the influence of relative roughness $y_{1} / D$ to be negligible (Chatterjee et al. 1994; Rajaratnam 1981; Sarathi et al. 2008) at least when the steady state of the scour is approached. In our tests, relative roughness is very low, if compared to similar studies, ranging between 1.78 and 3.97. Influence of the parameter has been considered negli- 
gible at this stage, according to the afore mentioned authors. It has been chosen to be very low, by using coarse material, as a starting point in anticipation of future tests when it will be increased in order to verify its influence on the scour features further. Furthermore, the choice of a coarse granulometry allowed to run tests with high densimetric Froude numbers without having bed load transport for undisturbed flow downstream and thus without having any material flowing out of the system.

Other authors supposed the influence of jet Reynolds number to be negligible as well (Espa and Sibilla 2006; Johnston 1990; Rajaratnam 1981).

Under these assumptions, the functional form for the generic scaled problem feature at the asymptotic state becomes:

$$
N_{\Phi}=f\left(s, F_{d}, S, \vartheta\right)
$$

\section{RESULTS AND DISCUSSION}

\section{Visual observations}

The achievement of a real steady state, where the grains stop moving (meaning that the bed shearstress is below its critical value) and the bed profile shape remains constant in time was rarely observed. A most common situation occurring during the tests was the achievement of a sort of "dynamic steady state". At this asymptotic state, grains were still moving but their movement didn't significantly affect the scour shape, as it had cyclic features: grains were still picked up from the bottom of the scourhole but promptly replaced by other grains. The way this cyclic equilibrium is maintained mostly depends on the jet regime, as it will be explained ahead.
As other authors noted before (Espa and Sibilla 2006; Johnston 1990), different jet regimes could be observed on the basis of visual observation of the grains movement. Then, different mechanisms holding a dynamic equilibrium of the bed profile occurred, depending on the jet regime.

A first regime, occurring at high submergence conditions, is similar to the so called "bed only scourhole regime" (Johnston 1990). A second one, occurring instead at shallow tailwater conditions, is similar to the so called "bed - surface scourhole regime" (Johnston 1990).

When the first mentioned regime occurs, the main jet is located at the bottom of the bed with a counter clockwise rotating vortex above; when the second mentioned regime occurs the jet oscillates cyclically between the "bed regime" and a "surface regime", where the main jet is located near the surface and a clockwise rotating vortex arises below. A similar situation has also been observed by (Espa and Sibilla 2006).

When the "bed regime" occurs, a dynamic equilibrium is maintained because of the ridge that develops downstream the scourhole. The ridge appears to have an upstream slope which is steep enough to make the grains, that are being pushed forward by the jet, roll back toward the bottom of the scourhole.

When the "oscillating regime" occurs grains are pushed toward the sluice gate opening by the lower vortex of the surface jet. When the jet switches to the bed regime, it pushes the grains back toward the bottom of the scour hole. This continuous jet regime oscillations cause the establishment of a dynamic equilibrium asymptotic state. When this kind 
of regime occurs, the jet appears to stay close to the surface for the most part of the time.

A so called "surface only regime" (Johnston 1990) has never been found during the course of this set of experiments.

On the basis of the visual observations made during the course of the experiments "bed only regime" has been found at higher tailwater conditions while lower tailwater conditions caused "oscillating regime" to occur.

\section{Time development of bed geometry}

Scourhole geometry development is usually faster at the beginning of the test (approximately in the first hour in our set of tests), and then it slows down dramatically. Some authors (Ali and Lim 1986;
Chatterjee et al. 1994) found a power law to be suitable for describing the time evolution of some of the scour geometric features.

No effort has been made by the authors of the present work yet to find a time evolution law for the process. Nevertheless, it's possible to observe that an asymptotic state is reached sooner for the scour maximum depth of erosion and maximum ridge height than for their lengths. Figure 2 shows the time evolution of the bed profile in one of the tests (id. 09):

Figure 3 shows the differences in time evolution for scour parameters. In the figure the superscript ' $*$ ' denotes non dimensional units: scaling length is $y_{1}$, while scaling time is $y_{1} / U_{1}$ ratio. Plotted parameters are, accordingly to Figure 1:

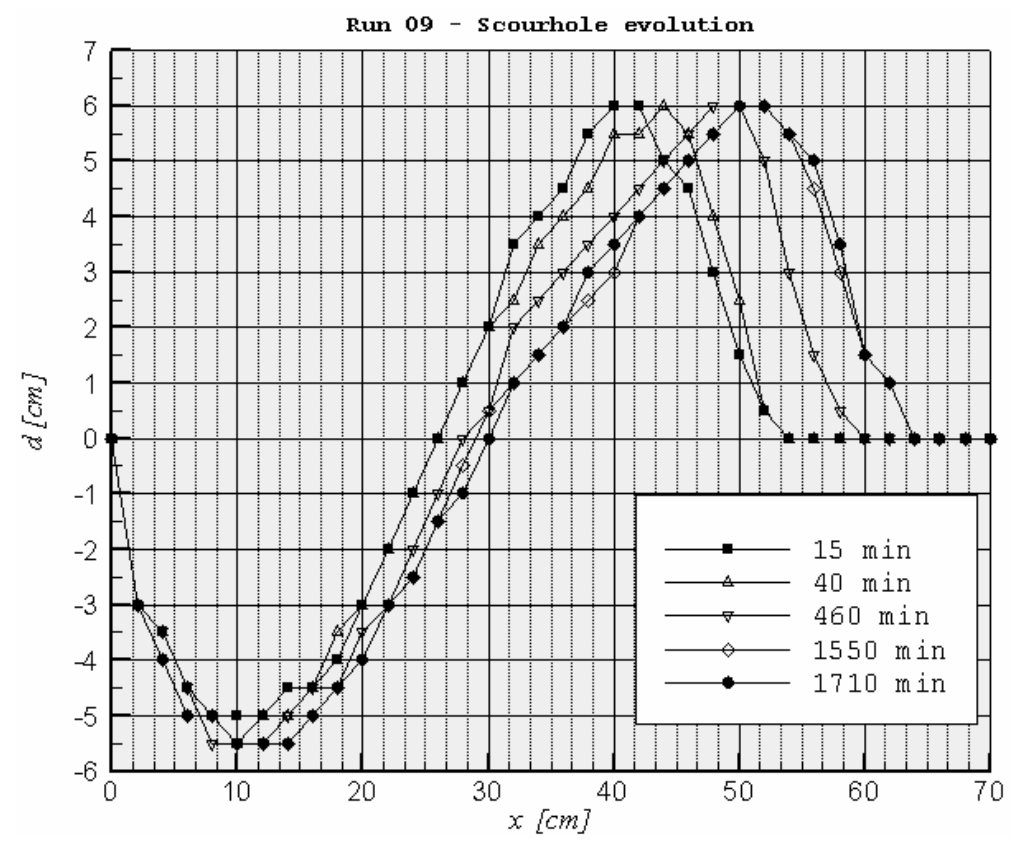

FIGURE 2. Scourhole time evolution for tests no 9 


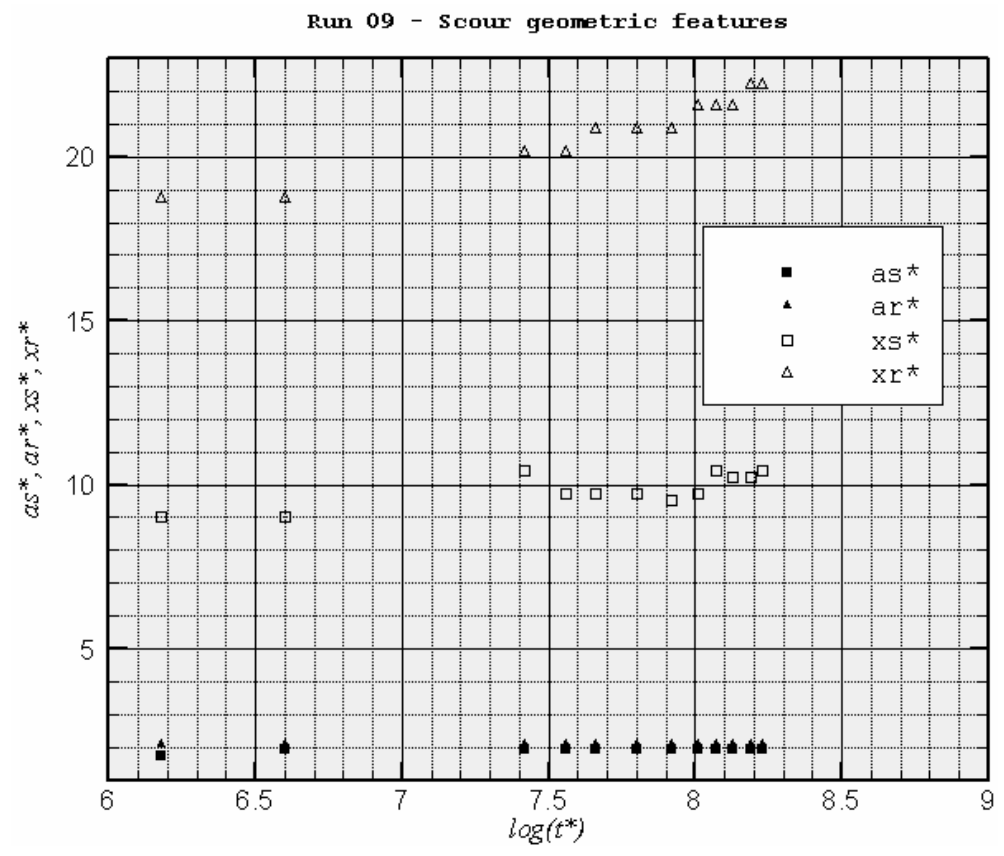

FIGURE 3. Scourhole parameters time evolution for test no 09

- Max scour depth (scaled): $\mathrm{a}_{\mathrm{s}}{ }^{*}$

- Max ridge height (scaled): $a_{r}{ }^{*}$

- Scourhole horizontal extension (scaled): $\mathrm{x}_{\mathrm{s}}^{*}$

- Ridge horizontal extension (scaled): $\mathrm{x}_{\mathrm{r}}^{*}$

\section{Asymptotic bed geometry}

The same kind of sediments has been used through all the whole set of experiments, and so relative roughness isn't properly taken into account in the run tests as only one value of diameter has been tested. A similar consideration applies regarding specific gravity of sediments, as water jets only have been used.

An asymptotic state has always been reached in our tests (even though it wasn't exactly a steady state, as previously explained, the evolution of the bed profile could be considered completed) indicating that the dependency of the final geometric features of the scour on the scaled time parameter can be ignored.

On the non dimensional time parameter can be canceled for Under these assumptions and considerations, the functional form listed in (3), is used for the final geometric features of the scour:

$$
N_{\Phi}=f\left(F_{d}, S, \vartheta\right)
$$

Maximum scour hole depth $a_{s}$ (see Fig. 1) only has been considered as a relevant geometric feature at this stage of the study. Its dependency on the parameters indicated in the right hand side of (4) has been investigated. Results are shown in the graphs of Figure 4 and Figure 5 where apron inclination and densimetric Froude number are held constant 

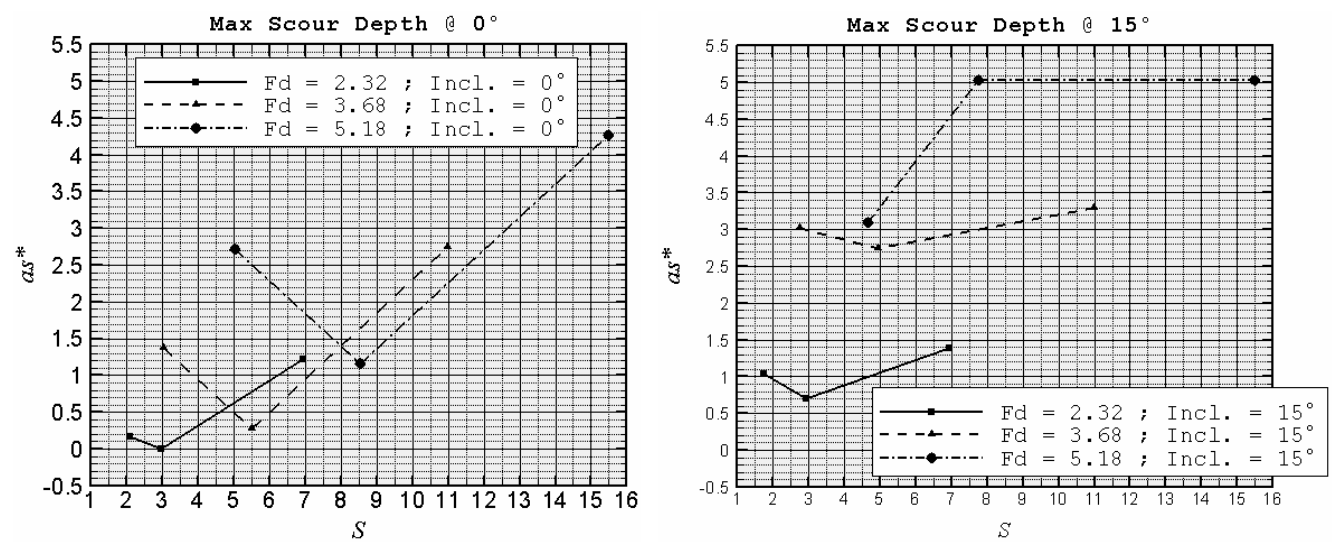

FIGURE 4. Max scour depth at constant inclination
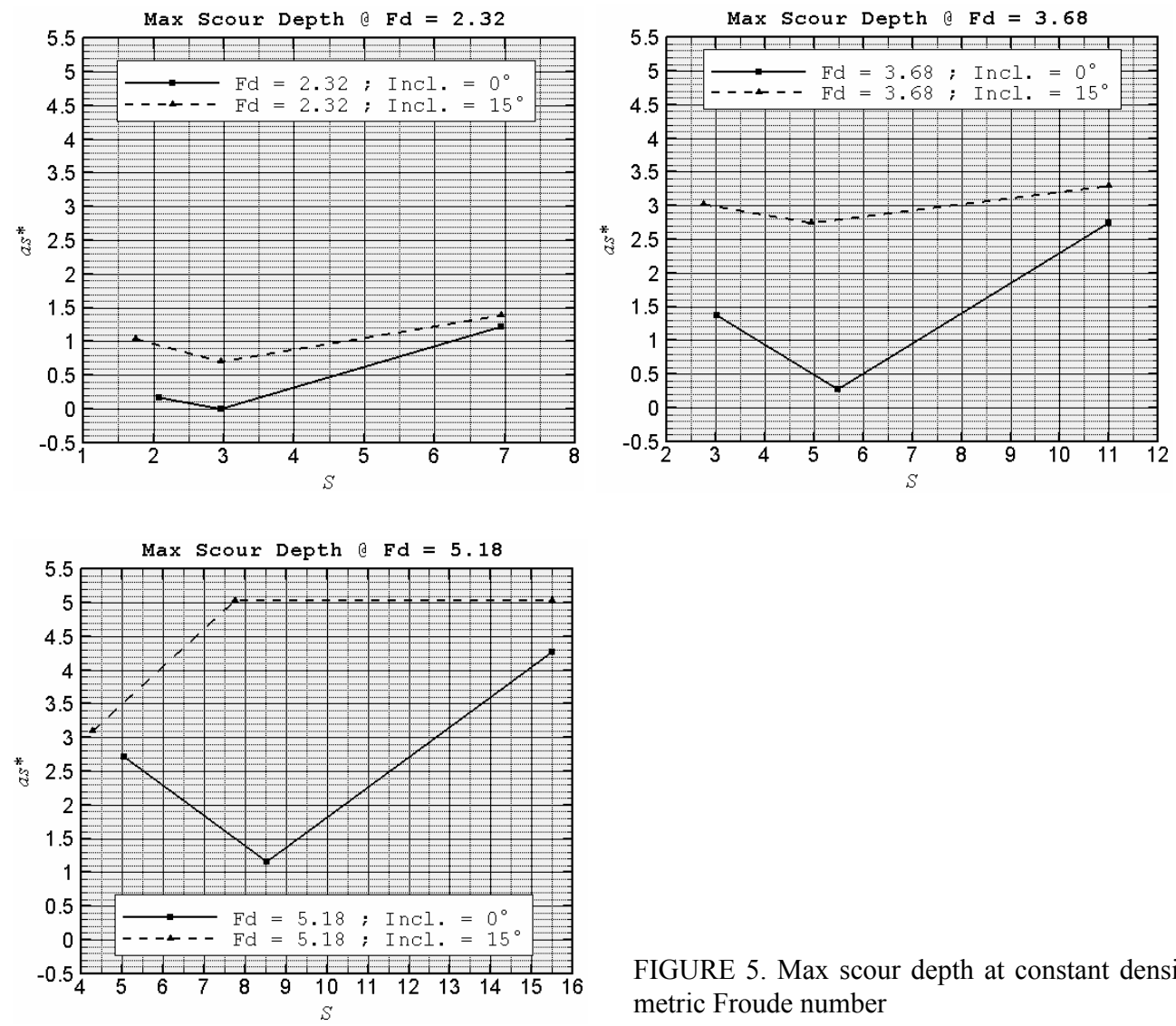

FIGURE 5. Max scour depth at constant densimetric Froude number 


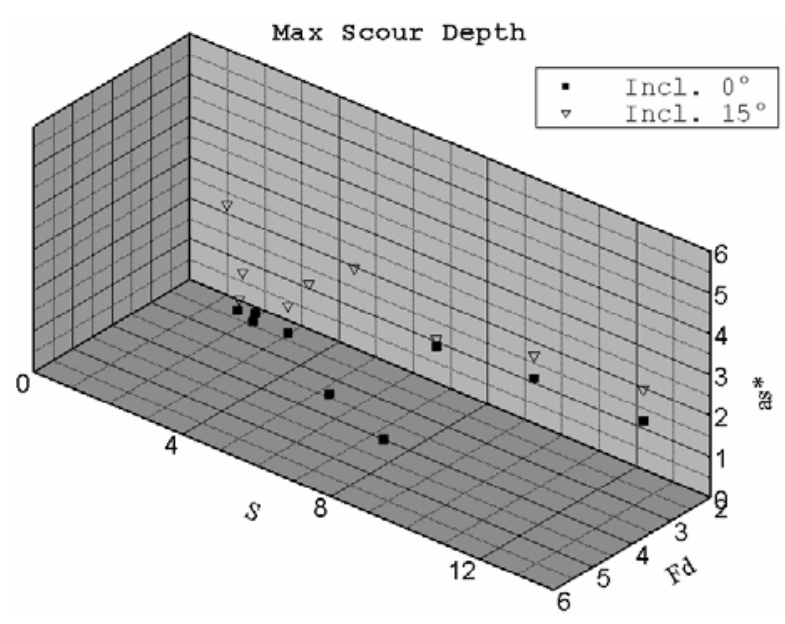

FIGURE 6. Influence of problem parameters on max scour depth

respectively. Finally, an overview on the experimental results obtained so far on maximum scour depth, is provided by Figure 6.

Results regarding maximum scour depth seem to indicate the presence of a critical submergence value causing a minimum value. The existence of this critical submergence value seem to exist regardless of the tested inclinations except for $\theta=15^{\circ}$ and $F_{d}=5.18$ (Fig. 4). Nevertheless, the minimum in scour depth might still exist in such conditions and for $\mathrm{S}<4.26$ but further tests should be done in order to verify this hypothesis.

As far as the apron inclination influence is concerned, it seems that jets passing over inclined aprons are responsible for creating deeper scours even though this tendency appears more markedly at low submergence values, as it can be seen from Figure 5 and Figure 6. It might be possible that, similarly to what seems to happen with submergence, there exists a critical value for inclination (at inclinations higher than $15^{\circ}$ ), causing a maximum in scour depth.

\section{CONCLUSIONS}

The present work shows the preliminary laboratory results regarding scour caused by a jet issued from a sluice gate. The effect of jets with different thickness and inclination angle has been studied on a mobile and uniform grains size bed at different tailwater conditions.

A set of suitable scaled parameters to be used to study the problem has been found by means of dimensional analysis.

Two different jet regimes have been observed: a "bed regime", where the jet stays attached to the bottom of the bed and an "oscillating regime" where the jet oscillates between the bed regime and a surface regime. The same behavior has been previously observed by other authors $[3,4]$, and the tailwater conditions causing a "bed regime" have been found to be in agreements with the ones indicated by Johnston (1990).

Finally, a critical value of submergence, causing a minimum in scour depth has been observed during the tests. The existence of a such conditions has been reported by other authors before (Ali and 
Lim 1986; Sarathi et al. 2008). The existence of a similar critical value also in jet inclination is possible; further developments regarding the validity of this assumption are in progress.

The results obtained so far show the influence of parameters regulating the phenomenon on the scour depth. When applied on experimental scale, the behavior of the physical system is described accurately enough. As far as the applicability of the results to a larger scale is concerned, it should be noted that the experimental phenomenon has been studied in a two dimensional configuration: behavior of the system which may be related to three dimensional effects hasn't been taken into account and it is not clear whether their influence would lead to scalable properties or not. Furthermore, before making any assumption regarding the phenomenon at a larger scale, more investigation should be made in order to get a deeper insight on the influence of other parameters: to name a few, the effect of different material sizes (possibly using smaller grains) and of solid inflow could be considered.

\section{REFERENCES}

ALI K.H.M., LIM S. 1986: Local scour caused by submerged wall jets. Proc. Instn. Civ. Engrs., Part 2, 81, 607-645.

CHATTERJEE S.S., GHOSH S.N., CHATTERJEE M., 1994: Local scour due to submerged horizontal jet. Journal of Hydraulic Engineering, 120(8), 973-992.

ESPA P., SIBILLA S., 2006: Studio sperimentale dei regimi di scavo a valle di una piastra di protezione in condizioni intermedie di sommergenza. $X X X^{\circ}$ Convegno di Idraulica e Costruzioni Idrauliche - IDRA 2006.

JOHNSTON A.J., 1990: Scourhole developments in shallow tailwater. Journal of Hydraulic Research, 28(3), 341-354.
NIK HASSAN N.M.K., NARAYANAN R., 1985: Local scour downstream of an apron. Journal of Hydraulic Engineering, 111(11), 1371-1385

RAJARATNAM N., 1981: Erosion by plane turbulent jets. Journal of Hydraulic Research, 19(4), 339-358.

RAJARATNAM N., MACDOUGALL R.K., 1983: Erosion by plane wall jets with minimum tailwater. Journal of Hydraulic Engineering, 109(7), 1061-1064

SARATHI P., FARUQUE M.A.A., BALACHANDAR R., 2008: Influence of tailwater depth, sediment size and densimetric Froude number on scour by submerged square wall jets. Journal of Hydraulic Research, 46(2), 158-175.

Streszczenie: $O$ erozji wywolanej wyplywem spod zasuwy. W referacie przedstawiono wstępne doświadczenia i badania dotyczące procesów wyboju w rozmywalnym podłożu wywołane przez nachylone strumienie wypływające spod zasuwy. Przeprowadzono doświadczenia dla zatopionej wody dolnej dla różnych przepływów i warunków geometrycznych. Badane warunki doświadczalne zawierały różne liczby Frouda strumienia, nachylenia strumienia i warunki wody dolnej. Konfiguracja dna była rejestrowana w czasie całego procesu ewolucji wyboju aż do osiągnięcia dynamicznego stanu ustalonego, gdzie ruch rumowiska był nadal możliwy, mimo że nie wywoływał dalszej stałej zmiany wyboju ani odkładu rumowiska. Na bazie obserwowanego ruchu rumowiska dwa różne układy przepływu mogą się tworzyć w badanych warunkach: jeden - gdy główny strumień pozostaje przyczepiony do dna kanału i inny - gdzie strumień oscyluje między poprzednio wymienionym i strumieniem powierzchniowym. Pewne parametry zostały zidentyfikowane i wykorzystane przy wykonaniu wykresów wykazujących ich korelacje i trendy.

\section{MS. received April 2010}

Authors' address:

Department of Civil and Environmental

Engineering, Firenze University

Via S. Marta 3

50139 Firenze (FI)

Italy

e-mail:1minatti@dicea.unifi.it 